
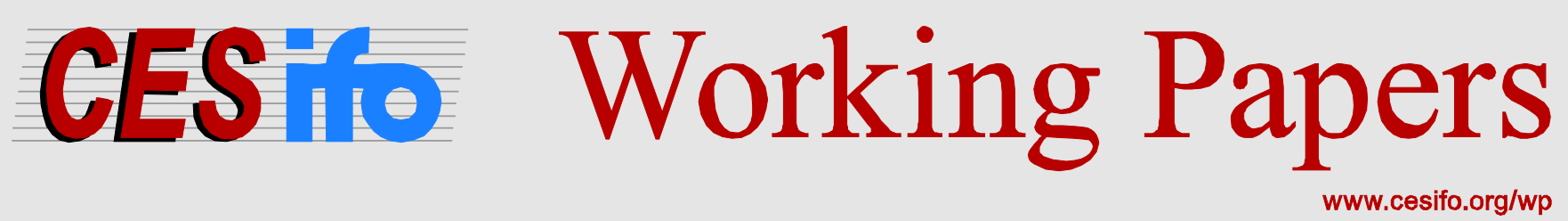

\title{
Policy Innovations, Political Preferences, and Cartel Prosecutions
}

\author{
Vivek Ghosal \\ D. Daniel Sokol
}

CESIFO WORKING PAPER NO. 5543

CATEGORY 11: INDUSTRIAL ORGANISATION

OCTOBER 2015

\author{
An electronic version of the paper may be downloaded \\ - from the SSRN website: Www.SSRN.com \\ - from the RePEc website: Www.RePEc.org \\ - from the CESifo website: www.CESifo-group.org/wp
}




\title{
Policy Innovations, Political Preferences, and Cartel Prosecutions
}

\begin{abstract}
While price-fixing cartel prosecutions have received significant attention, the policy determinants and the political preferences that guide such antitrust prosecutions remain understudied. We empirically examine the intertemporal shifts in U.S. antitrust cartel prosecutions during the period 1969-2013. This period has seen substantive policy innovations with increasing penalties related to fines and jail terms. There appear to be four distinct cartel policy regimes: pre-1978, 1978-1992, 1993-2003, and 2004-2013. Our empirical estimates show significant variation in the number of cartels prosecuted and the penalties imposed across the policy regimes. The more recent regimes are characterized by far fewer cartels prosecuted, but with substantially higher penalties levied on firms and individuals. While effective deterrence is one explanation for these patterns, we are more inclined to conclude that US cartel enforcement has seen an underlying shift away from focusing on smaller cartels to larger and multinational firms. In terms of political effects, our results reveal no clear inter-political party effect on cartel prosecutions, but there appear to be interesting intra-political party effects. We find that particular Presidencies matter for cartel prosecutions, and variation across Presidential administrations led to marked shifts in the total number of cartels prosecuted. Overall, the shifts in the number of cartels prosecuted and penalties levied portray changing policy priorities and a search for the optimal enforcement design to curtail one of the clearest sources of welfare loss, collusion.
\end{abstract}

JEL-Code: K210, L410, L130, L110.

Keywords: cartels, collusion, price-fixing, enforcement, prosecutions, antitrust, leniency, fines, jail terms, Antitrust Amendments Act, ACPERA, politics, business cylces.

\author{
Vivek Ghosal \\ School of Economics \\ Georgia Institute of Technology \\ Atlanta / Georgia / USA \\ vivek.ghosal@econ.gatech.edu \\ http://www.econ.gatech.edu/people/faculty/ghosal http://www.law.ufl.edu/faculty/d-daniel-sokol \\ D. Daniel Sokol \\ Levin College of Law \\ University of Florida \\ Gainesville / Florida / USA \\ sokold@law.ufl.edu
}

September 14, 2015

For valuable suggestions and comments, we thank conference participants at NYU Law School, Yale Law School, University of Minnesota School of Law, University of California-Berkeley Law School, Social Sciences Korea International Conference on Competition Law Enforcement (Yonsei University), Indian Institute of Management Bangalore, Indian Institute of Management Ahmedabad, Research Institute for Industrial Economics (Stockholm), University of Melbourne, Workshop on Applied Microeconomics (CESifo, Munich), and Roger Blair, Dennis Carlton, Harry First, Douglas Ginsburg, Jinook Jeong, Al Klevorick, Margaret Levenstein, Barak Orbach, George Priest, Eric Rasmussen, and Larry White. We are extremely grateful to Bob Feinberg for extensive and constructive comments on an earlier version of this paper. 


\section{Introduction}

Prosecution of price-fixing cartels has been perhaps the biggest growth area of antitrust enforcement globally. Fines for price-fixing have reached record levels in recent years, which has brought increased attention to antitrust. Yet, the determinants of antitrust cartel prosecutions remain understudied. Our paper examines the policy determinants and the political preferences that may guide such cartel prosecutions.

We examine the long-run evolution of U.S. cartel enforcement by examining its three major attributes: number of cartels prosecuted, fines for corporations and individuals, and incarceration for individuals. The changes resulted from major policy innovations in public enforcement, particularly leniency. Higher financial penalties and greater incarceration reinforced the leniency mechanism. As we detail later, based on these changes, we note four distinct policy regimes: pre-1978, 1978-1992, 1993-2003, and 2004-2013. These policy initiatives were designed to minimize the incentives to form cartels, as well as to destabilize existing cartels.

The transformation of cartel policy as part of optimal antitrust enforcement occurred at about the same time that much of antitrust underwent significant change doctrinally. Many of the transformations of antitrust enforcement in this period were a function of an intellectual shift in part due to Chicago law and economics scholars. ${ }^{1}$ These scholars advocated a fundamental change in the then existing U.S. antitrust law and policy based on moving liability from per se to rule of reason due to potential efficiencies of the behavior in question.

Cartel enforcement played a smaller role for the Chicago School overall, which focused on the reform of merger and monopolization enforcement. ${ }^{2}$ The lack of the emphasis on cartels was due both in part to the overall confusion by the courts as to other areas of law as well as the fact that conceptually cartel enforcement was "low hanging fruit" - the identification of harm by cartel behavior from the standpoint of consumer welfare was simple. The per se application of liability to hard core cartels made them less effective and destabilized them. ${ }^{3}$ The present structure of cartel enforcement with high fines, significant incarceration, an emphasis on large international cartels and the use of leniency is very different from what concerned academic writing from Chicago or other scholars until the 1990s.

Our paper contributes to the literature in two key dimensions. First, we conduct a detailed analysis of the evolving policy regimes, and quantify their effects on the total number of cartels prosecuted, and the penalties per firm and individual. Our work sheds light on previous theoretical work that examines deterrence with regard to enforcement tools and cartel formation. ${ }^{4}$ Further, a number of papers have modeled how leniency provides incentives to improve detection because leniency may destabilize cartels. ${ }^{5}$ By examining alternative policy regimes, we extend the empirical work in this area. As far as we are aware, such a detailed analysis is not available using data over such a long time period.

\footnotetext{
${ }^{1}$ Bork (1978), Posner (1976), Demsetz (1973), Stigler (1964), Director and Levi (1956), Bowman (1957), McGee (1958) and Tesler (960).

${ }^{2}$ A number of Chicago School scholars supported financial penalties only and opposed incarceration (Becker 1968, Posner 1976, Elzinga and Breit 1976).

${ }^{3}$ Bork (1978, pp. 263, 268).

${ }^{4}$ E.g., Chang and Harrington (2014) and Miller (2009).

${ }^{5}$ E.g., Spagnolo (2004), Chen and Harrington (2007) and Harrington (2008).
} 
Second, we conduct an extensive analysis of political effects. In doing so, we extend prior work examining political preferences. ${ }^{6}$ Given our long time period, we are able to examine both inter-political party as well as intra-political party effects. The broader policy differences across various Presidential administrations have been stark. Our analysis allows us to examine whether the overall policy differences also extended to the area of cartels.

In our empirical analysis we use data over a 45-year period, 1969-2013, to examine the intertemporal dynamics of cartel prosecutions. Our estimates show marked differences across the policy regimes in the number of cartels prosecuted, and the penalties imposed. Across the policy regimes, the number of cartels prosecuted have declined, while the fines levied per firm and per individual increased dramatically. We also find interesting results related to political effects; there is little evidence of inter-political party effects, but more revealing intra-political party effects. ${ }^{7}$ In our empirical estimation we control for the prosecution variables' own dynamics, as well as business cycles and the agency's overall workload.

The paper is organized as follows. In section 2, we describe some of the key cartel enforcement and institutional changes from 1890 to the present. ${ }^{8}$ In section 3 we describe the data, and develop the empirical specification in section 4 . We present the empirical results in Section 5. In section 6 we briefly note issues related to cross-jurisdictional cartel enforcement, by the European Commission, and scope for further research in this area. Final discussion and concluding remarks appear in section 7 .

\section{Policy Changes, Politics, and Cartel Prosecutions}

\subsection{Literature on Cartel Enforcement}

Antitrust enforcement has often been modeled based on an optimal deterrence framework. Firms will be deterred when the expected costs to the firm of undertaking illegal activity exceed the expected benefits to them based on a calculation of the probability and magnitude of the penalties (Becker 1968). Becker's framework was has been explicitly applied to antitrust by for some time (Landes 1983; Feinberg 1980; Block, Nold and Sidak 1981). However, the optimal deterrence framework pervades the work of earlier antitrust scholars in how they approached institutional design issues, including in the area of cartel prosecution.

The empirical questions of cartel detection and stability assume that one can determine the overall number of cartels. Due to the illegality of cartels, their contracts to collude are not enforceable by law and are hidden. Thus, determining the total number of cartels that exist is difficult. What can be measured more easily as a proxy for cartel stability is the number of

\footnotetext{
${ }^{6}$ E.g., Long, Schramm and Tolison (1973), Siegfried (1975), Posner (1970), Gallo, Dau-Schmidt, Craycraft and Parker (2000), Ghosal (2011a, 2011b), Ghosal and Gallo (2001) and Ghosal and Sokol (2014). Most papers focus on change in party of the President, which may shift resources within DOJ across criminal and civil conduct and mergers because of a change in enforcement philosophy. In general, it is assumed that Democrats are overall more pro- enforcement while Republicans are more laissez fair.

${ }^{7}$ For example, we find that under Reagan, the period associated most with a shift to Chicago thinking and one of a relative lack of enforcement (Pitofsky, 2008), cartel prosecutions reached their peak in the post-WWII era. However, during the George W. Bush presidency, a presidency also defined by its Chicago antitrust approach (Baker and Shapiro, 2008), there is a precipitous drop in the number of cartels prosecuted relative to Reagan (as well as Clinton and Obama).

${ }^{8}$ In this paper we study U.S. federal cartel prosecution and do not examine state level enforcement as has been done by Feinberg and Reynolds (2010).
} 
prosecutions, particularly of cartels in which there is hard evidence of collusion. Most of the time within US antitrust enforcement, such hard evidence emerges from cooperation of a defecting cartel member via the leniency program (Hammond 2010).

Nevertheless, there may be a bias as to the types of cartel cases prosecuted due to the mix of leniency and penalties. It may be that more sophisticated companies are able to use leniency strategically to punish rival firms (Chen and Rey 2013; Sokol 2012). Levenstein and Suslow (2010) provide some empirical support to suggest that the attributes of convicted cartels show little sophistication in their collusion strategies. However, as an overall strategy, we draw linkages between the effects of prosecutions on cartel behavior and model unoberserved violations.

If we assume that cartel activity remains under-deterred (Levenstein \& Suslow 2014), then we can also assume that more severe penalties with regard to higher corporate fines and increased jail time for individuals, along with a well-designed leniency program (Spagnolo 2008) will bring enforcement closer to optimal. Presently, we remain uncertain as to whether increased number of cartels prosecuted is due to more effective methods of uncovering cartels (Spagnolo 2008), a growth in the total number of cartels based on economic factors (Eckbo 1976; Levenstein \& Suslow 2011, 2006), or the political attributes of antitrust enforcers based on agency priorities (Ghosal 2011b).

\subsection{Key Developments in U.S. Cartel Enforcement}

Cartel policy developments have shifted over time. These developments have resulted in three specific changes: higher fines for corporations and individuals, higher jail sentences for individuals, and the increasing use of the leniency program. In this paper, we measure criminal cartel prosecutions by the Department of Justice Antitrust Division. These prosecutions require a violation of Section 1 of the Sherman Act. We begin our study with the 1960s, after the impact of the first major cartel prosecution to capture general public attention - the heavy equipment cartel. We examine the period before the introduction of the original leniency program of 1978 as one period, ${ }^{9}$ as this period saw important shifts in institutional structures of cartel enforcement. Cartel fines during the early part of this period, which had been raised in the 1950s, were low by today's standards, even when adjusted for inflation. Cartel activity also was a misdemeanor rather than a felony until 1974. Changes that increased financial penalties and incarceration and that introduced leniency were all innovations to increase the punishments associated with cartel behavior and a higher probability of detection. As for white collar crimes generally, the introduction of these penalties have a lag time until they make their way into policy because of an existing pipeline of cases.

To motivate the empirical analysis in Section 5, we provide an overview of the critical events in the timeline of cartel policy. Such developments provide context to explain the empirical results. We divide by issue the key developments within cartel prosecutions across the themes of fines, incarceration and leniency.

\subsubsection{Fines}

In 1890 the Congress passed the Sherman Act. The statute set the maximum fine at $\$ 5,000$. In 1955, Congress raised the maximum fine under the Sherman Act to \$50,000 per count. Fine levels remained constant until 1974, when Congress enacted the Antitrust Procedures and Penalties

\footnotetext{
${ }^{9}$ Though the original leniency program was introduced in 1978, DOJ Antitrust had been discussing the leniency program since 1976, according to senior DOJ Antitrust officials at the time with whom we conferred.
} 
Act (APPA). Under APPA, Congress increased the maximum penalties for collusion to \$1 million. Thereafter, the statutory level for fines remained constant until the Antitrust Amendments Act of 1990. The Act increased maximum fines to $\$ 10$ million for corporations and $\$ 350,000$ for individuals. The next time that the level of fines increased for cartel conduct was 2004 when Congress passes the Antitrust Criminal Penalty Enhancement and Reform Act (ACPERA). ACPERA increased the maximum cartel fine for firms to $\$ 100$ million, and the individual fine to $\$ 1$ million. ACPERA also created a treble damage exemption for private piggyback cases after leniency. Further, since 1996 the alternative sentencing mechanism allowed fines greater than the Sherman Act statutory maximum.

\subsubsection{Incarceration}

Originally under the Sherman Act, cartel offenses were classified as misdemeanors rather than as felonies. This meant that criminal terms were one year or under for a violation of the Sherman Act. Jail was not a preferred penalty. Incarceration was used once in $1921^{10}$ and not again until 1959. ${ }^{11}$ With the enactment of APPA, cartel crimes were transformed from a misdemeanor to a felony and the maximum term of imprisonment for collusion was increased from one year to three years. Further, DOJ promulgated Guidelines (1977) to advocate higher levels of incarceration, which signaled a shift in the seriousness to increase penalties on the part of the government. ${ }^{12}$ The first case in which a court imposed maximum prison terms under the 1974 statute was $1981 .^{13}$

Further penalty enhancement came in 1987 when the US Sentencing Guidelines (passed in 1984) were applied to cartel offenses. ${ }^{14}$ The Antitrust Amendments Act of 1990 increased prison terms to up to three years. Prison terms increased again in 2004 under ACPERA to a maximum of 10 years. $^{15}$

\subsubsection{Leniency}

DOJ introduced the original US leniency program in 1978. Leniency allowed for a company to blow the whistle on its cartel participation and to ask for a penalty reduction. This leniency program proved to be ineffective ${ }^{16}$ because granting leniency was totally at DOJ's discretion, even in situations in which a firm met all of the requirements of leniency (full cooperation) and that leniency was conditioned upon a request prior to DOJ beginning its cartel investigation.

In 1993, DOJ revamped the leniency program. Under the revised leniency program, DOJ provided the leniency applicant automatic amnesty if there was no pre-existing cartel investigation and there was full cooperation. Further, amnesty was available even when cooperation began after

\footnotetext{
${ }^{10}$ United States v. Alexander \& Reid Co., 280 Fed. 924, 927 (S.D.N.Y. 1922)

${ }^{11}$ United States v. McDonough Co., 1960 Trade Cases (CCH) ๆ 69,695 (S.D. Ohio, 9 December 1959).

12 This was based on a then famous speech by DOJ Antitrust head Don Baker in 1976. See Baker (1976, 2011).

${ }^{13}$ U.S. v. B\&B Construction Co.

${ }^{14}$ Until the implementation of the Sentencing Guidelines, judges were reluctant to impose significant sentences on white collar offenders.

${ }^{15}$ As a consequence, the US Sentencing Guidelines were amended in 2005 to reflect this change based on lobbying by the Department of Justice Antitrust Division. See Hammond (2005).

${ }^{16}$ Only one leniency application was received per year and not a single leniency application was for an international cartel (Hammond 2004). An important issue also is that DOJ's resource allocation changed shortly after the introduction of leniency. In 1979, the Hart Scott Rodino Act of 1976 went through its first full year of implementation. The first year of merger filing notifications totaled over 800 filings. Increasingly, merger control became far more resource intensive, potentially distracting from other areas of enforcement.
} 
an investigation. Finally, in situations when a corporation qualified for automatic amnesty, all directors, officers, and employees also received automatic amnesty based on full cooperation. Leniency was introduced for individual applicants in 1994.

The first use of revised leniency occurred in 1995 for the lysine cartel. The companies settled with DOJ in 1996 for criminal fines of $\$ 105$ million, a then record amount. ${ }^{17}$ The majority of lysine cartel members were international (Connor 2001). Before 1995, fewer than 1 percent of all DOJ cartel indictments involved non-US conspirators. Other significant international cartel cases quickly followed. ${ }^{18}$ At present, nearly all of DOJ's cartel investigations are a result of the leniency program. (Hammond 2010).

\section{Data Description}

The primary data we use are from DOJ's historical enforcement statistics for the number of cartels prosecuted, number of individuals and corporations prosecuted, fines, and incarcerations, among others, for the period 1969-2013. ${ }^{19}$ We start in 1969 as most of the variables we use are not available before that. We end in 2013 as that was the last year for which data were available when we started the project. The U.S. macroeconomic data comes from the Federal Reserve Bank of St. Louis. In some of our empirical analysis, we control for economy-wide merger activity to control for DOJ's overall workload. The data on total number of mergers in the U.S. are from the Federal Trade Commission merger series (1958-1977) and Thompson's Financials (1978-2013). All monetary data are measured in real 2005 dollars. In table 2 we present the summary statistics for the variables we use in our estimation in section 5.

To motivate our econometric analysis, the prosecutions and penalties data are displayed in figures 1-6. Figure 1 shows that prior to 1979-80, the mean number of cartel cases were about 20 per year. It rose sharply during the Reagan years to about 60 cases per year. Thereafter, it fell steadily to a low of 25-30 cases per year during the George W. Bush years, before showing an uptick during the Obama years. While the pre-1980 period typically contains uniformly low number of prosecutions, the post-1980 period reveals a mixed picture with highs reaching almost 100 cases (mostly local cartels under Reagan and George H.W. Bush administrations) and lows of about 25. An interesting observation is that in the aftermath of 1993 leniency program restructuring, the actual number of cartels prosecuted declined somewhat.

A different pattern emerges in figures 2 and 3 which show the intertemporal patterns for fines and jail days per cartel prosecuted. The penalties were relatively flat till about the mid-1990s, and increase after that. Figures 4 and 5, which display fines per firm and individual, show a similar pattern. Finally, figure 6 displays the jail days per individual; unlike the fines, this series shows a steady increase over time. The cartels that have generated the largest fines in the US during the period 1995-2013 include: Air cargo, DRAM, TFT-LCD and Vitamins cartels.

Overall, the story that emerges from the historical data on U.S. cartel prosecutions is that the main changes appear to be fewer cartels prosecuted but with increased severity of penalties in terms

\footnotetext{
17 The year 1996 also marked the first use of the alternative fine statute (18 USC 3571(d)).

${ }^{18}$ As ICPAC (2000, at chapter 4) noted, the change in international priorities and the effect of new leniency were significant within a short time span. "From 1987 through 1990, the Antitrust Division did not file a single criminal cartel case against a foreign-based corporation or individual...By 1997, the figures had surged so that 32 percent of corporate defendants and the same number of individual defendants were foreign-based.”

${ }^{19}$ For a number of variables related to penalties the starting point of the data is 1970 .
} 
of incarceration and fines since the mid-1990s. The mid-1990s correspond to the period when the leniency program was restructured. The figures suggest that introduction of the revised leniency program, along with the Antitrust Amendments Act (1990) and ACPERA (2004) significantly impacted cartel related penalties. The clear message is that the severity of penalties has increased dramatically only in the more recent years. ${ }^{20}$ In addition to the 1990 Antitrust Amendments Act and the 2004 ACPERA increasing penalties, there was also the start of the alternative fine calculations under 18 U.S.C. § 3571(d).

\section{Empirical Specification}

In this section we examine whether the institutional changes related to leniency and the new penalty programs, among other factors we consider below, had measurable effects on the full array of cartel enforcement variables. We structure our specification by first focusing on the cases prosecuted, and then discuss estimation for the fines and incarceration effects.

There are multiple forces that are likely to influence DOJ's cartel enforcement path. We outline a framework to structure our empirical specification and note the set of variables are likely to affect DOJ's decisions. We assume that DOJ maximizes the number of cases subject to minimizing some function of two costs: (1) adjustment costs, which arise for DOJ due to resource constraints given by the number of attorneys, economists and funding, implying that actual intertemporal change in DOJ's case activity may be less than the desired change in order to minimize adjustment costs (Ghosal 2011b); and (2) disequilibrium costs, which could arise as DOJ is subject to potential pressures from the political arena, antitrust lawyers and economists, and producer and consumer groups (Coate, Higgins and McChesney 1990). If DOJ's enforcement stance is markedly above or below the desired level, there may be pressure to rectify this, potentially bringing unwanted scrutiny and publicity. This framework is, therefore, a reasonable strategy to structure the econometric specification to model the intertemporal path of cartel enforcement. ${ }^{21}$

The above framework results in the well-known partial-adjustment model, Cases $_{t}-$ Cases $\left._{t-1}\right)=\lambda\left(\right.$ Cases $_{t}^{*}-$ Cases $\left._{t-1}\right)$ where the actual change in cartel cases $\left(\right.$ Cases $_{t}-$ Cases $\left._{t-1}\right)$ is a fraction $\lambda(0 \leq \lambda \leq 1)$ of the desired change Cases $_{t}^{*}-$ Cases $\left._{t-1}\right)$, with $\lambda$ being the adjustment-cost parameter. $^{22}$ Rearranging we get: $\operatorname{Cases}_{t}=(1-\lambda) \operatorname{Cases}_{t-1}+\lambda \operatorname{Cases}_{t}^{*}$. Next, the equilibrium or desired number of cartel cases, Cases $_{t}^{*}$, is modeled as a function of the relevant driving variables. We model the equilibrium number of cartel cases, $\operatorname{Cases}_{t}^{*}$, as: $\operatorname{Cases}_{t}^{*}=$ $f\left(\right.$ Violations $_{t}$, Policy $_{t}$, President $\left._{t}, \boldsymbol{X}_{t}\right)$. We describe the variables below. Since the relevant factors typically take time to impact the number of cartel cases, in our estimation we consider current year as well as lagged values of the variables where relevant.

Turning to the variables that determine $\operatorname{Cases}_{t}^{*}$, we include the following:

\footnotetext{
${ }^{20}$ Changes in case law as to a tightening of procedural antitrust (Twombly and Matsushita) may have shifted prosecutions and overall cartel enforcement as well.

${ }^{21}$ This is a widely used modeling strategy to examine the dynamic path of variables has been to consider a decisionmaker's objective to minimize the expected present value of a quadratic loss function subject to adjustment and disequilibrium costs. The conceptual and theoretical underpinnings of this framework are spelled out in, for example, Hendry et al. (1983) and Kennan (1979).

${ }^{22}$ If $\lambda$ is closer to 1 it would imply that adjustment to the new equilibrium/desired level takes places almost instantly, whereas $\lambda$ closer to 0 implies slower adjustment process.
} 
(a) Unobserved Violations. The population of price-fixing violations are unobserved, and we model this below.

(b) Institutional and policy variables (Policy). As we noted earlier, several administrative and legal milestones have affected cartel enforcement. It is widely recognized by antitrust scholars and DOJ that the old leniency program started in 1978 was ineffective. ${ }^{23}$ DOJ restructured the leniency program and the new program went into effect in 1993, with the first leniency settlements in 1996 (Lysine case). ${ }^{24}$ Given this, we focus on the 1993 date. We focus on two other institutional innovations: the Antitrust Amendments Act (1990) which increased fines and jail terms (which because of the lag get included with the leniency innovation); and ACPERA (2004) which further increased fines and jail terms.

Using these distinctive changes, we create four policy regimes as follows:

1) Policy1: if year $\leq 1977$, representing the pre-old leniency regime. The level of fines and jail were low during this period by statute and policy;

2) Policy2: if $1978 \leq$ year $\leq 1992$, representing the old leniency regime. The old leniency regime period averaged fewer than one application per year. Fines and jail terms were higher than pre-1977 but still relatively low compared to the current era;

3) Policy3: if $1993 \leq$ year $\leq 2003$, representing the new leniency regime, as well as the effects of the Antitrust Amendments Act. ${ }^{25}$ New leniency reshaped cartel enforcement by uncovering large international cartels. Fines and jail time increased and international cartel members were sent to US jail; and

4) Policy4: is $2004 \leq$ year $\leq 2013$, representing the ACPERA (2004) changes. This is the current legal regime. Fines and jail terms have increased beyond prior levels.

(c) Political factors (President). Examining the potential Presidential effect is interesting because of the institutional structure of the Antitrust Division. The Assistant Attorney General, who heads the Antitrust Division, is appointed directly by the U.S. President, potentially setting the stage for shifts in enforcement with changes in the President and their specific priorities. ${ }^{26}$ In alternative specifications we either use a Presidential dummy (Republican=1; Democrat=0), or include a dummy

\footnotetext{
${ }^{23}$ Chen and Harrington (2007), Hammond (2004, 2010), and Motta (2004).

${ }^{24}$ While these factors have transformed cartel enforcement, in the bigger picture these changes can be viewed as endogenous to broader shifts in intellectual thinking about cartel enforcement and the political willingness to prosecute (Baker, 2002; Ghosal, 2011b; and Kovacic and Shapiro, 2000).

${ }^{25}$ Due to the extensive overlap of time periods, we cannot include separate dummies for the new Leniency period and the Antitrust Amendments Act. However, it is important to note that Policy2 covers the period 1978-1992, so AAA - which went into effect right at the end of 1990 - is really at the tail end of our Policy2 period. Our contention is that any meaningful effect of AAA will be felt in Policy3 period which starts 1993, as opposed to Policy2 (which ends in 1992). There was a lag time for the AAA to really take effect in the court; this occurred during the 1995-1999 period in which DOJ was able to get fines of \$10 million of more (against 27 different companies). Note that this lag matches very nicely with the new leniency, which begins in earnest in 1996 with fines in the lysine cartel. A lagged effect is also important because it was some time until the U.S. Sentencing Guidelines and alternative fining statutes really took hold for cartels. So our imputing the AAA effect to the Policy3 period is reasonable.

${ }^{26}$ The number of cartel cases in the post-WWII period was approximately 20 per year through the Carter years. Prosecutions increased by $112 \%$ during the Reagan administration, and the upswing continued during the George H.W. Bush administration. Since then, the number of cartel cases has tapered off, followed by a marked reduction of prosecutions under George W. Bush administration. There was an uptick during the Obama administration. Ghosal (2006, 2011a, 2011b) surveys the literature and presents estimates on political and Presidential effects for the full range of antitrust enforcement variables; however, in these earlier papers there was no treatment of the alternative policy and institutional regimes that we consider here, along with other differences such as a longer time period and a more detailed consideration of political effects.
} 
for each President. As we discuss later, including the Policy(.) variables and the dummies for individual Presidents causes collinearity among several variables due to extensive overlap of time periods. This implies that it is difficult to identify both the Policy(.) and individual Presidential effects in the same estimated specification.

(d) Other variables (vector $\boldsymbol{X}$ ). We consider several variables as controls:

1) DOJ's investigative workload (Busy). We alternatively use two variables to control for DOJ's workload: (a) total number of antitrust investigations - which is our main control variable as it represents the Division's total workload; (b) combinations of other types of investigations such as total preliminary investigations, Civil Investigative Demands, noncartel investigations; and (b) the economy-wide M\&As as measured by the frequency of merger filings. The argument is that periods of large number of total investigations or M\&A activity may swamp the Antitrust Division with merger clearance and investigative work, potentially taking resources away from cartel enforcement. By itself, this may tend to reduce cartel prosecutions. However, in selected instances, examination of merger-specific or monopolization information during routine investigations may serve as one of the conduits for information about collusive activity in markets, leading to increase in cartel prosecutions (Ghosal, 2008 and 2011a).

2) Macroeconomic conditions (Cycle). Examining the effects of business cycles on cartel activity is a common in the literature. ${ }^{27}$ Our main control variable is the percentage change in GDP (GDP).

We also considered DOJ's funding as an additional variable. An increase in DOJ's funding may lead to greater investigative resources and increases in cartels discovered and prosecuted. However, the previous empirical literature finds little to no evidence of a link between funding and cartel cases (or for that matter non-cartel cases). ${ }^{28}$ Our initial experiments showed this to be the case in our estimated specifications. Given this, we do not include this variable in our reported specifications.

Next we model the unobserved number of price-fixing violations as: Violations $_{t}=$ $f\left(\right.$ Policy $_{t}$, President $\left._{t}, \boldsymbol{Z}_{t}\right)$. Violations are expected to respond to the Policy and President regimes, and $\boldsymbol{Z}$ is a vector containing lagged-dependent variable, Cycle and Funds. Since the Policy(.) regime dummies capture differential levels of fines and jail terms and account for deterrence effects, we do not include fines and jail terms as separate variables in our estimated specifications. The justification for Cycle and Funds are similar to those described for Cases $_{t}{ }^{29}$

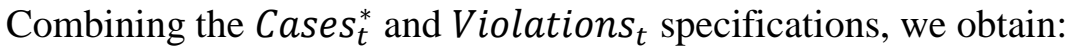

\footnotetext{
${ }^{27}$ Baker (1989), Dick (1996), Ghosal (2008, 2011a), Levenstein and Suslow (2006), Scherer (1980), Slade (1990) and Suslow (1988, 1991).

${ }^{28}$ See, e.g., the discussion in Ghosal (2011b).

${ }^{29}$ With introduction of Policy(.) features like leniency, high fines and incarcerations regime, we expect higher deterrence and less collusion. Similarly, if a President regime is such that it is placing greater emphasis on cartel enforcement, detection and prosecution, we expect collusion to be lower due to the increased likelihood of detection and penalties. The argument regarding Cycle remains same as before: we expect the propensity to engage in collusion to be higher when economic conditions are weak due to the relationship to low demand. Regarding Funds, availability of greater investigative resources signals potentially more vigorous enforcement. Since this is a relatively transparent signal, it is potentially expected to influence firms' behavior towards fewer anti-competitive activities.
} 


$$
\begin{aligned}
& \text { [1] } \text { Cases }_{t}=\gamma_{0} \\
& +\sum_{k=1}^{n}\left[\delta_{k} \text { Cases }_{t-k}+\zeta_{k} \text { Policy }_{t-k}+\phi_{k} \text { President }_{t-k}+\varphi_{k} \text { Busy }_{t-k}+\tau_{k} \text { Cycle }_{t-k}\right] \\
& +\omega_{t} \text {. }
\end{aligned}
$$

Specification (1) serves to fully describe the dynamic path of cartel prosecutions.

In section 5, we estimate (1) using the data on the total number of cartels prosecuted, as well as other variables that capture different aspects of overall cartel enforcement and prosecutions. These include variables such as fines per cartel, jail days per individual, number of individuals and firms convicted per cartel, among others. The rationale for including other aspects of prosecutions and enforcement is that the per firm or per individual penalties should be part of the calculation that cartel members are likely to make in whether or not to pursue cartel activity, and boards and other senior managers to invest in cartel prevention/compliance if they are law abiding firms. The number of firms and individuals convicted per cartel provides some signal of the scope of the cartel itself, as well as the efforts of the DOJ to snare as many culprits as possible. These variables will likely impact deterrence because of the amount law abiding firms will expend on compliance and unlawful companies will invest in trying to cover up their cartel behavior.

While fines are expected to increase with higher statutory limits, such as under AAA and ACPERA, it is not obvious that fines per firm or per individual should be increasing. This depends on the scope of the cartel. If large multinational firms are caught, due to their size and volume of commerce, fines will be larger. If small firms are caught fixing process of gasoline, then fines will be low. ${ }^{30}$ Given this, examining the effects of policy and other variables on the per capita penalties is a meaningful exercise.

Overall, the total number of cartels prosecuted captures the total effort in both inputs and outputs from DOJ in its ant-cartel efforts. Fines for corporations and individuals and number of days in jail provide an understanding of the willingness of DOJ (and courts) to move actual penalties higher based on the existing statutory limits for penalties. A higher rate signals an increased ability and willingness to increase the enforcement severity, which in turn may increase the deterrent effect for other potential or actual cartels observing DOJ policy. For each of the variables we use, we estimate a parsimonious specification (1) to quantify the effects of Policy(.) and politics, our two main interests.

\section{Estimation Results}

First we examine the estimates in table 3. All specifications include a lagged-dependent variable, lagged GDP growth to capture potential business cycle effects, and Busy (as DOJ's workload control). Column 1 presents estimates for the total number of cartel cases prosecuted. The Presidential dummy (Republican=1 v. Democrat=0) captures any broad political effects. Given that

\footnotetext{
${ }^{30}$ For example, consider the following two scenarios. Scenario A: 100 cartel members get caught and each pays a fine of $\$ 0.5$ million, for total fines worth $\$ 50$ million. Scenario B: 2 bigger/sophisticated cartels members get caught and each pays a fine of $\$ 250$ million, for total fines worth $\$ 500$ million. In the above hypothetical, total fines are same in the two scenarios. But the total fine conceals important underlying differences in fines per firm. If the per firm fines paid significantly increase, it also indicates that very likely much bigger cartels are being snared. If these were two gas stations in a one-red-light town fixing prices, one would not get \$250 million fine per firm.
} 
there are a total of four Policy(.) dummies, we include three in the estimated specification, with the fourth one (we use Policy1 for this) acting as the baseline dummy captured by the intercept term.

For cartels prosecuted, GDP growth and Busy are not significant. ${ }^{31}$ Neither is President, indicating that on average, there is no difference between Republican and Democratic Presidential regimes in the total number of cartels prosecuted. Of the policy variables, only Policy2 is positive and significant. The Policy2 period is 1978-1992, the old leniency period. While this variable is positive and significant, the interpretation is complicated by the fact that this period also covers the Reagan years which saw a marked increase in cartel prosecutions (more on this in section 5.1). The fact that the specification includes a general Presidential dummy does not entirely solve this inference problem. Overall, for total number of cartels prosecuted, the Policy(.) variables play a limited role, and that there is no systematic political effects.

For the estimates from the fines and jail days per cartel specifications, we see a somewhat different pattern. The Policy(.) variables are positive, significant and with increasing impact over time, thus tallying with our prior that these regimes successfully ratcheted up the deterrent variables related to fines and incarceration. The overall Presidential dummy continues to be insignificant. Examining the aggregate fines and jail terms (last two columns) gives us very similar inferences regarding the Policy(.) and Presidential effects.

Next we examine the results in table 4, which present estimates for individual and firm penalties. For the number of individuals and firms prosecuted per cartel, all the Policy(.) coefficients are significant and negative, implying that the successive Policy(.) innovations resulted in a smaller number of individuals and firms prosecuted per cartel. As before, the general Presidential dummy is insignificant implying no Republican v. Democratic effect on average.

Finally, we comment on the three penalties variables: 'fines per firm', 'fines per individual', and 'jail days per individual'. For these, the Policy(.) estimates are all positive and significant (barring the Policy2 estimate for the first column). This indicates that the policy regimes on average successfully ratcheted up the penalties. The general Republican v. Democratic Presidential dummy is positive, but insignificant for three of the specifications, implying no political effect on average.

The last column in table 4 presents estimates for the ratio of individuals jailed to those sentenced. This variable can be viewed as a measure of prosecutorial efficiency. Only the Policy4 effect is significant, and a quantitatively large estimate. The general Presidential dummy is insignificant. Overall, these estimates indicate a substantial increase in prosecutorial efficiency under the ACPERA period, 2004-2013.

Based on our examination of the results in tables 3 and 4, we draw the following conclusions:

1. The Policy(.) innovations over our 45 year period generally lead to a decrease in the number of individuals and firms prosecuted per cartel (table 4), and no effect on the total number of cartels prosecuted (table 3). In contrast, the total fines and jail days per cartel prosecuted increased

\footnotetext{
${ }^{31}$ As noted earlier in section 4, we use the total number of investigations (all categories) by the Antitrust Division as our main workload control. We experimented with alternate variables to control for this. For example, in the estimated regressions we replaced the total investigations variable by: other types of workload variables such as preliminary investigations, CIDs, non-cartel investigations; and M\&As. As with the main variable we use to proxy Busy, these alternate variables were not significant and do not alter our overall inferences. As this is one of the control variables and not the main focus of the paper, to save space we do not add additional tables.
} 
dramatically (table 3). In addition, fines per individual, fines per firm, and jail days per individual, also increased over the successive Policy(.) innovations (table 4). ${ }^{32}$ One explanation for some of the patterns, e.g., fewer cartels prosecuted, is that cartel prosecutions have led to deterring cartel formation and longevity.

However, the dramatic increase in the fines levied per firm and per individual, and the jail terms, tells us that there is more to the story. Increase in these imply that the average cartel caught had to be large. Therefore, perhaps a clearer way to summarize this information would be that fewer cartels were caught on average across the successive Policy(.) regimes, but those that were caught were, on average much larger cartels - as manifested by the size of the total and per capita penalties, which are related to the amount of social welfare loss of a collusion case. The fines per firm and per individual simply could not be this large if the typical cartel caught was small. These attributes appear indicative of an underlying policy shift towards focusing on the larger and multinational firms.

2. Regarding political effects, if we believe that the correct approach is to capture politics simply by Republican v. Democratic Presidents, then we find no political effect. However, if we believe that the correct way to capture this is to include a specific dummy for each President, then there appears to be no clear way to separate the Policy(.) innovations from potential political effects. Given the extensive time-period overlaps between the Policy(.) and specific Presidential periods, there is no easy way to disentangle these two competing forces as both sets of variables cannot be used together in the estimated specification. We discuss this further in section 5.1 .

\subsection{A Simple Exercise on Disentangling the Policy and Political Effects}

Overall, the results in table 3 point to important Policy(.) driven effects, but it is difficult to cleanly separate the policy from the political effects. One of the reasons why this separation is important is that even under a given Policy(.) regime, different presidents may have different preferences, and appoint more or less aggressive AAG's to implement their policy objectives.

The reason we could not include specific Presidents in column 1 is that these dummies are collinear with the included Policy(.) variables. We conducted the following exercise to provide a perspective. We estimated specification (2) - which is specification (1) with the President variable excluded:

[2] Cases $_{t}=\gamma_{0}+\sum_{k=1}^{n}\left[\delta_{k}\right.$ Cases $_{t-k}+\zeta_{k}$ Policy $_{t-k}+\varphi_{k}$ Busy $_{t-k}+\tau_{k}$ Cycle $\left._{t-k}\right]+\omega_{t}$.

This is designed to wipe out the systematic influences of the included variables. Based on this, figure 7 shows the actual number of cartels prosecuted, the estimated long-run mean level of cartels, and the estimated effects of Policy2, Policy3 and Policy4 periods. We display the mean level of actual cartel prosecutions by Presidential period.

\footnotetext{
32 The clear effects under our estimation of ACPERA contrast with Miller (2009) and Sokol (2012). Most likely, these earlier papers did not capture a lag from ACPERA's passage to effects on enforcement. Miller's data consist of all indictments and information reports filed for violations of Section 1 of the Sherman Act between January 1 , 1985, and March 15, 2005. Though this period is sufficient to explore the revised 1993 leniency program's effects, the data endpoint of March 2005 is clearly not enough time to examine the 2004 ACPERA effects. Sokol's data consists of both qualitative and quantitative survey data of cartel practitioners but soon after passage of ACPERA.
} 
Figure 7 reveals that during the Policy2 period, the mean levels of prosecutions under Reagan and George H.W. Bush administrations were similar, ${ }^{33}$ but much higher than under Carter. The mean level of prosecutions under the Clinton administration, during Policy3 period was lower than the previous two administrations.

Perhaps the most interesting observation is that within the Policy4 period, there is a sharp difference between the George W. Bush and Obama administrations, with the level of prosecutions under George W. Bush is below the estimated long-run mean level of prosecutions. ${ }^{34}$

In similar vein, we plot the two main penalty variables in figure 8 (fines per cartel) and figure 9 (jail days per cartel). Unlike figure 7 on the total number of cartels prosecuted, figures 8 and 9 show that the penalty structure essentially remained the same until the George H.W. Bush administration but with the same penalty structure as across the Policy4 regime.

As we noted in section 4, political preferences are most likely to affect whether DOJ actively pursues cases, but is less likely to manifest itself in penalties once a case is pursued. The inferences regarding politics and cartel enforcement would be for more enforcement under Democrats or constant enforcement across Republican administrations. However, Regan and George H.W. Bush presidencies yielded greater number of cartel prosecutions than Carter and Clinton and the George W. Bush presidency yielded fewer cartel prosecutions than Clinton or Obama administrations.

\section{European Cartel Prosecutions}

US cartel prosecution may not operate in isolation of developments worldwide. One issue we did not address is that some of the developments in U.S. cartel prosecutions and cartel detection, particularly within the Policy3 and Policy4 regimes, may be related to events in other jurisdictions. In particular, some of the U.S. prosecutions could be related to developments in European cartel prosecutions. In this section we briefly note some issues, without conducting formal econometric analysis, which is left for future extensions.

European cartel enforcement has gone through periods of shifts in prosecution tools, which we summarize. The first legal prohibition against collusion was in the 1957 Treaty of Rome. Cartel enforcement for decades was sparse. ${ }^{35}$ Significant fines and prosecution of cartels did not begin until after the First Leniency Notice in 1996. Shortly thereafter in 1998, the Commission issued its First Guidelines on the method of setting fines. That was the same year as the first leniency applicant (Tate \& Lyle) in the sugar cartel.

European policy initiatives increased during the 2000s, perhaps in response to US developments. The EC provided its Second Leniency Notice in 2002, which provided immunity for ongoing investigations. Cartel enforcement became decentralized under Regulation 1/2003, which

\footnotetext{
${ }^{33}$ It has, however, been noted that these were local cartels with limited effects (Levenstein and Suslow, 2008).

${ }^{34}$ During the George W. Bush period, there was also a drop in DOJ civil antitrust enforcement and in merger enforcement based on case counts. While there has been critique of low enforcement during George W. Bush, none of the critiques in policy (Varney, 2009) or academic (Baker and Shapiro, 2008) circles discussed the low total number of cartel cases.

${ }^{35}$ In 1962, Regulation 17/62 set the maximum penalty at $10 \%$ of annual turnover for a firm. The first cartel infringement decision was in 1969 in the Quinine case, in which the penalty was 500,000 European Unit of Account, with the first fine of 1 million European Current Unit (which replaced EUA) in 1982 (Schinkel, 2007).
} 
allowed then Article 81 application by national courts and agencies. The regulation also increased powers of investigation and set up European Competition Network (ECN). In 2006, DG Competition introduced its Second Guidelines on the method of setting fines, the Third Leniency Notice, which attempted to increase transparency (and create a marker system) and the ECN Model Leniency program (to harmonize leniency across the EU). In 2008, DG Competition introduced its settlement notice, which provided a $10 \%$ discount to participating firms. The first settlement case was in 2010. Finally, in 2012 the EU introduced its Second ECN Model Leniency program.

The small European empirical cartel literature to date suggests a similar trend in enforcement to that of the United States. Schinkel (2007) provides a survey of EU cartel enforcement until that time, while Carree, Gunster and Schinkel (2010) offer a broader survey of European enforcement that includes cartels. Stephan (2009) examines the empirics of leniency in Europe while more recent work by Marshall, Marx and Mezzetti (2015) analyze the impact of European leniency applications with regard to multimarket colluders. Other works shows the number of cases and leniency applicants have risen dramatically since 2003, relative to earlier periods (Aguzzoni, Langus and Motta 2013).

In figure 10 and figure 11 we display the total number of EC cartel prosecutions and the fines per cartel, respectively. The time-path of the fines per cartel series looks relatively similar to the U.S. (figure 2), with fines rising dramatically after around the year 2000. However, the number of cartels prosecuted is very low; the average over the full sample period is only 4.5 cartels per year. The highest observation is 10 cartels prosecuted in 2001. These numbers are vastly lower than the U.S. sample mean of approximately 45 per year, with a high of 96 prosecuted in 1984 . The argument that EU Member States have their own cartel prosecutions is unlikely to explain this gaping difference as one can, in similar vein, argue that U.S. states also prosecute cartels.

The overall EC v. U.S. comparisons look a bit puzzling, and the aggregated data we use do not lend themselves to a clear framework for econometric analysis to examine the dynamic interlinkages. Perhaps the better solution for examining EC-US dynamics is to examine specific cases that each jurisdiction prosecuted, examine their origins, and then analyze whether one jurisdiction may have piggybacked on the other for specific cases. We are pursuing this line of inquiry in our ongoing analysis.

\section{Discussion and Concluding Remarks}

We find significant shifts in US cartel prosecutions over time with regard to specific policy innovations across the totality of public cartel enforcement which includes cases prosecuted, jail terms, and fines on individuals and corporations. These variables individually show significant intertemporal heterogeneity and divergent patterns.

Based on the data, we are able to identify four broad periods of U.S. cartel enforcement. The first period, before 1978 (and the original leniency program), saw relatively limited number of cartels prosecuted, along with minimal penalties as measured by fines and penalties. The second period, 1978-1992, saw dramatically higher number of cartels prosecuted, but only marginal increase in penalties. The third period, roughly starting 1993 (with the revised leniency program), is characterized by somewhat lower number of cartels prosecuted (relative to the second period), but dramatically higher fines and jail terms. The fourth period, 2004-2013 is the current regime in which jail terms and fines have increased beyond prior levels but in which the period shows a slight decline in the number of cartels prosecuted. 
The current stage, with dramatically higher penalties but not so high number of prosecutions, is suggestive of a clear shift in objectives. The new enforcement "net," so to speak, appears to be designed to catch larger cartels. While it is possible that fewer cartels are being caught is suggestive of a potential deterrence, the fact that the actual fines per firm and per individual are an order of magnitude larger, is clearly indicative of much bigger cartels caught; we would not get these characteristics if the typical cartel caught was small. If the focus on larger cartels is in fact the underlying policy shift, it could be justified on the grounds of proportionality to the degree of economic harm, as well as administrative efficiency.

Such policy shifts, however, have pros and cons. While this net is more likely to catch larger firms and multinational conspiracies, domestic local and regional cartel enforcement may suffer. The closing of important antitrust field offices, such as those of Atlanta, Cleveland, Dallas and Philadelphia during 2012-2013, are also indicative of underlying shifts in focus.

In the area of political effects, we find no meaningful difference between Republican and Democratic Presidents on average. However, there are important differences across Presidential administrations in the number of cartels prosecuted. For example, the George W. Bush administration (2001-2008) had an outlier-low level of prosecutions relative to other Republican administrations, such as Reagan and George H.W. Bush. This is somewhat contrary to the narrative that Republican administrations tend to focus more on cartel prosecutions because they are more tolerant of single firm behavior and of mergers.

A fruitful avenue for further research would be to examine the dynamic interlinkages between U.S. and European Commission cartel enforcement and prosecution patterns. The aspects related to different penalty regimes and forms of cooperation worldwide remain understudied but with increased global cooperation in cartel enforcement, some of the developments in Europe (and other jurisdictions) may impact cartel detection and stability for global cartels that also impact US cartel prosecution efforts, and vice versa. 
Ghosal \& Sokol. Policy, Politics, Cartel Enforcement | September 2015

\section{References}

Baker, Donald, 1976. To Make the Penalty Fit the Crime: How to Sentence Antitrust Felons, remarks before the Tenth New England Antitrust Conference (20 November 1976).

Baker, Donald, 2011. Criminalising Cartels: A critical interdisciplinary study of an international regulatory movement, Caron Beaton-Wells and Ariel Ezrachi, (eds.) Oxford: Hart Publishing.

Baker, Jonathan. 1989. "Identifying Cartel Policing under Uncertainty: The U.S. Steel Industry, 1933-1939.” Journal of Law and Economics 32, S47-76.

Baker, Jonathan and Carl Shapiro, (2008), "Reinvigorating Horizontal Merger Enforcement,” in Where the Chicago School Overshot the Mark: The Effect of Conservative Economic Analysis on Antitrust, Robert Pitofsky, (ed.), New York: Oxford University Press.

Becker, Gary. 1968. “Crime and Punishment: An Economic Approach,” Journal of Political Economy 76: 169-217.

Block, Michael Kent, Frederick Carl Nold and Joseph Gregory Sidak. 1981. "The Deterrent Effect of Antitrust Enforcement,” Journal of Political Economy, 89(3): 429-445.

Bork, Robert. 1978. The Antitrust Paradox. New York: Basic Books.

Bowman, Ward S. 1957. "Tying Arrangements and the Leverage Problem”, Yale Law Journal, 67: 19.

Chen, Joe and Harrington, Joseph E. 2007. "The Impact of the Corporate Leniency Program on Cartel Formation and the Cartel Price Path,” The Political Economy of Antitrust, Vivek Ghosal and John Stennek, (eds.). New York: Elsevier.

Chen, Zhijun and Patrick Rey. 2013. “On the Design of Leniency Programs,” Journal of Law and Economics 56, 917-957.

Choi, Jay Pil and Heiko Gerlach. 2014. "Cartels and Collusion - Economic Theory and Experimental Economics,” Oxford Handbook of International Antitrust Economics, Roger D. Blair and D. Daniel Sokol, (eds.). New York: Oxford University Press.

Coate, Malcom B., Richard S. Higgins, and Fred S. McChesney. 1990. "Bureaucracy and Politics in FTC Merger Challenges.” Journal of Law and Economics 33(2): 463-82.

Connor, John M. 2001. Global Price Fixing: Our Customers are the Enemy. New York: Springer.

Dick, Andrew. 1996. "When Are Cartels Stable Contracts?” Journal of Law and Economics 39, 24183.

Demsetz, Harold. 1973. "Industry Structure, Market Rivalry, and Public Policy." Journal of Law and Economics 16: 1-9. 
Department of Justice Antitrust Division, 1977. Guidelines for Sentencing: Recommendations in Felony Cases under the Sherman Act (24 February 1977).

Eckbo, Paul L. The Future of World Oil. Cambridge: Ballinger Publishing, 1976.

Elzinga, Kenneth G. and William Breit, 1976. The antitrust penalties: A study in law and economics (Yale University Press, New Haven).

Feinberg, Robert, and Kara Reynolds, 2010. “The Determinants of State-Level Antitrust Activity,” Review of Industrial Organization 37, 179-196.

Feinberg, Robert. 1980. “Antitrust Enforcement and Subsequent Price Behavior,” Review of Economics and Statistics, 62, 609-612.

Gallo, Joseph C., Kenneth Dau-Schmidt , Joseph L. Craycraft , Charles J. Parker. 2000. “Department of Justice Antitrust Enforcement, 1955-1997: An Empirical Study”, Review of Industrial Organization, 17:75-133.

Ghosal, Vivek. 2011a. “The Law and Economics of Enhancing Cartel Enforcement: Using Information from Non-Cartel Investigations to Prosecute Cartels.” Review of Law and Economics 7, $501-538$.

Ghosal, Vivek. 2011b. “Regime Shift in Antitrust Laws, Economics and Enforcement.” Journal of Competition Law and Economics 7, 733-774.

Ghosal, Vivek. 2008. “The Genesis of Cartel Investigations: Some Insights from Examining the Dynamic Interrelationships between U.S. Civil and Criminal Antitrust Investigations.” Journal of Competition Law and Economics 4, 61-88.

Ghosal, Vivek. “Economics, Politics and Merger Control.” In Recent Developments in Antitrust: Theory and Evidence, Jay Pil Choi (Ed.). MIT Press: Cambridge, 2006, Chapter 5, pages 125-152.

Ghosal, Vivek, and Joseph Gallo. 2001. “The Cyclical Behavior of the Department of Justice’s Antitrust Enforcement,” International Journal of Industrial Organization, 27-54.

Hammond, Scott. 2010. "The Evolution of Criminal Antitrust Enforcement Over the Last Two Decades,” Address before the 24th Annual National Institute on White Collar Crime, (February 25).

Hammond, Scott. 2005. Testimony before the United States Sentencing Commission, April 12, 2005, available at http://www.justice.gov/atr/public/testimony/209071.htm

Hammond, Scott. 2004. “Cornerstones of an Effective Leniency Program,” Address Before the ICN Workshop on Leniency Programs (November 22).

Harrington, Joseph. 2004. "Cartel Pricing Dynamics in the Presence of an Antitrust Authority," RAND Journal of Economics 35, 651-73.

Kennan, John. 1979. “The Estimation of Partial Adjustment Models under Rational Expectations,” Econometrica 47, 1441-1455. 
Klein, Joel. Prepared statement of Joel I Klein, Assistant Attorney General, Antitrust Division, U.S. Department of Justice, Before the Senate Judiciary Committee, Antitrust, Business Rights and Competition Subcommittee (May 4, 1999)

Landes, William M. 1983. “Optimal Sanctions for Antitrust Violations,” University of Chicago Law Review 50, 652-78.

Levenstein, Margaret, and Valerie Suslow. 2014. "Cartels and Collusion - Empirical Evidence,” Oxford Handbook of International Antitrust Economics, Roger D. Blair and D. Daniel Sokol, (eds.). New York: Oxford University Press.

Levenstein, Margaret, and Valerie Suslow. 2011. "Breaking Up Is Hard to Do: Determinants of Cartel Duration,” Journal of Law and Economics 54(2), 455 - 492.

Levenstein, Margaret, and Valerie Suslow. 2006. “What Determines Cartel Success?” Journal of Economic Literature 44, 43-95.

Levenstein, Margaret, and Valerie Suslow. 2004. "Studies of Cartel Stability,” in Peter Grossman (ed.), How Cartels Endure and How they Fail. Edward Elgar, 9-52.

Long, William, Richard Schramm and Robert Tollison. 1973. “The Economic Determinants of Antitrust Activity.” Journal of Law and Economics 16, 351-64.

McGee, John S. 1958. "Predatory Price Cutting: The Standard Oil (NJ) Case”, Journal of Law and Ecnomics 1: 137.

Miller, Nathan. 2009. "Strategic Leniency and Cartel Enforcement.” American Economic Review, 99, 750-768.

OECD. Recommendation of the Council Concerning Effective Action against Hard Core Cartels. Paris: Organization of Economic Cooperation and Development (1998).

Posner, Richard A. 1970. “A Statistical Study of Antitrust Enforcement”, Journal of Law and Economics, 365, pp. 365-419.

Scherer, Frederic. 1980. Industrial Market Structure and Economic Performance. Boston: Haughton Mifflin.

Siegfried, John. 1975. “The Determinants of Antitrust Activity.” Journal of Law and Economics 18.

Sokol, D. Daniel. 2012. “Cartels, Compliance and What Practitioners Really Think About Enforcement,” Antitrust Law Journal 78, 201-240.

Spagnolo, Giancarlo. 2008. "Leniency and Whistleblowers in Antitrust" in Paolo Buccirossi (ed), Handbook of Antitrust Economics (Cambridge, MIT Press, 2008).

Spagnolo, Giancarlo. 2004. Divide et Impera: Optimal Leniency Programs. CEPR Discussion Paper 4840. Available at www.cepr.org and www.ssrn.com. 
Ghosal \& Sokol. Policy, Politics, Cartel Enforcement | September 2015

Stigler, George. 1964. “A Theory of Oligopoly,” Journal of Political Economy 72, 44-61.

Suslow, Valerie. 1988. "Stability in International Cartels: An Empirical Survey.” Hoover Institution Working Paper No. E-88-7 (Stanford University).

Telser, Lester G. 1960. “Why Should Manufacturers Want Fair Trade?” Journal of Law and Economics, 3: 86.

Varney, Christine. 2009. "Vigorous Antitrust Enforcement in This Challenging Era,” Remarks as Prepared for the United States Chamber of Commerce, May 12, 2009. 
Figure 1. Total cartel cases

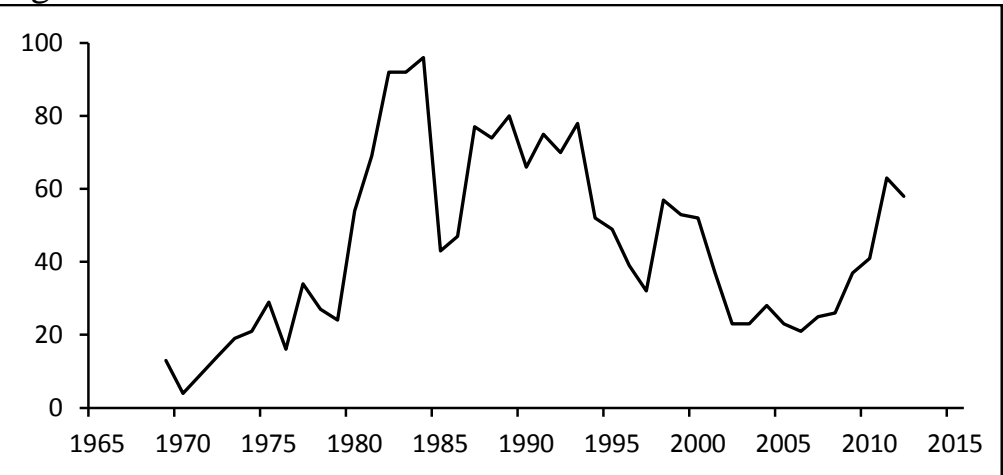

Figure 2. Fines per cartel (Real 2005 \$, '000)

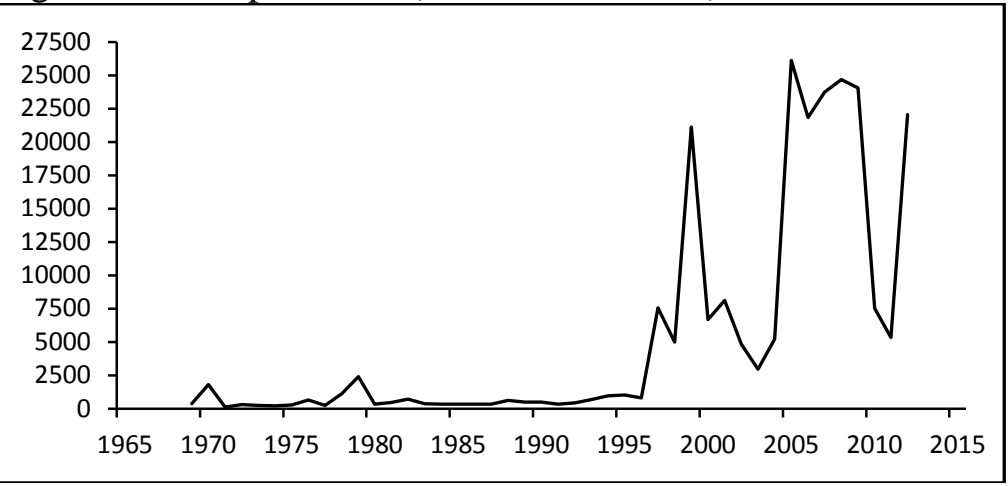

Figure 3. Jail days per cartel

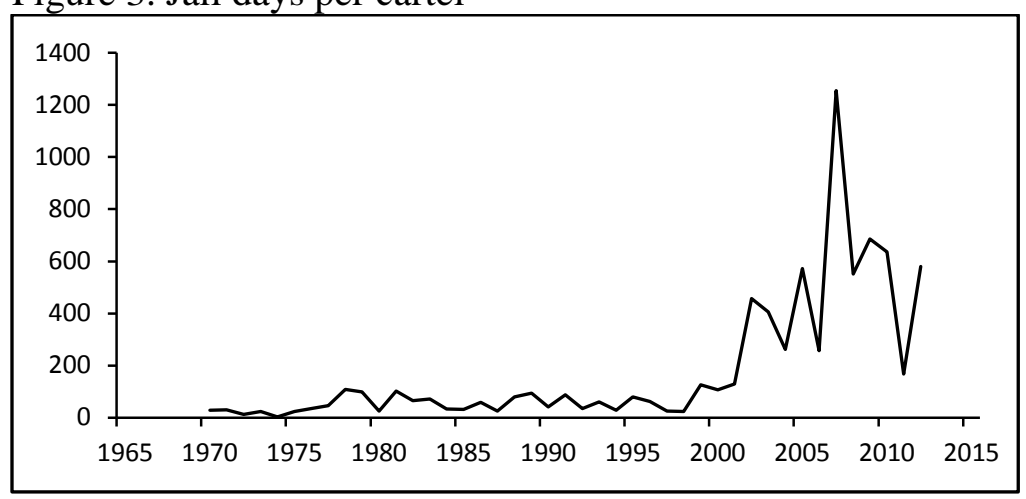


Figure 4. Fines per firm (Real 2005 \$, '000)

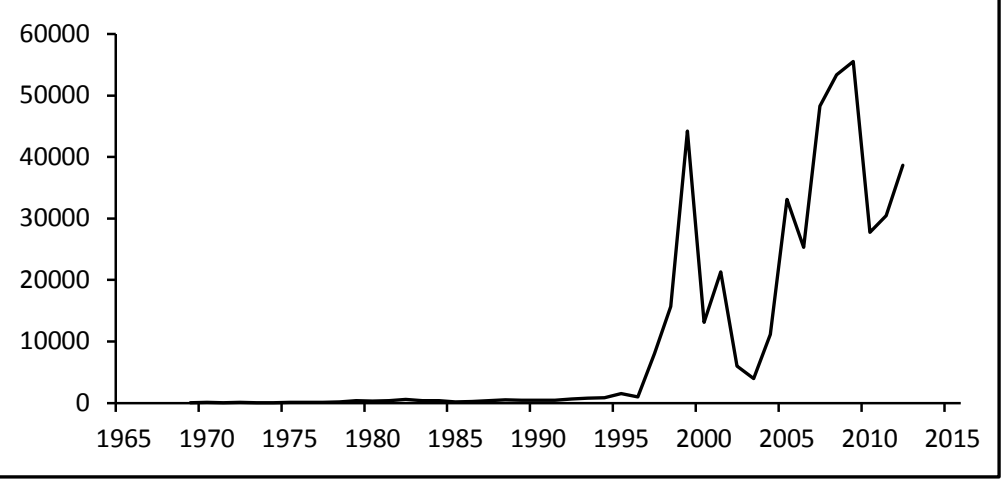

Figure 5. Fines per individual (Real 2005 \$, '000)

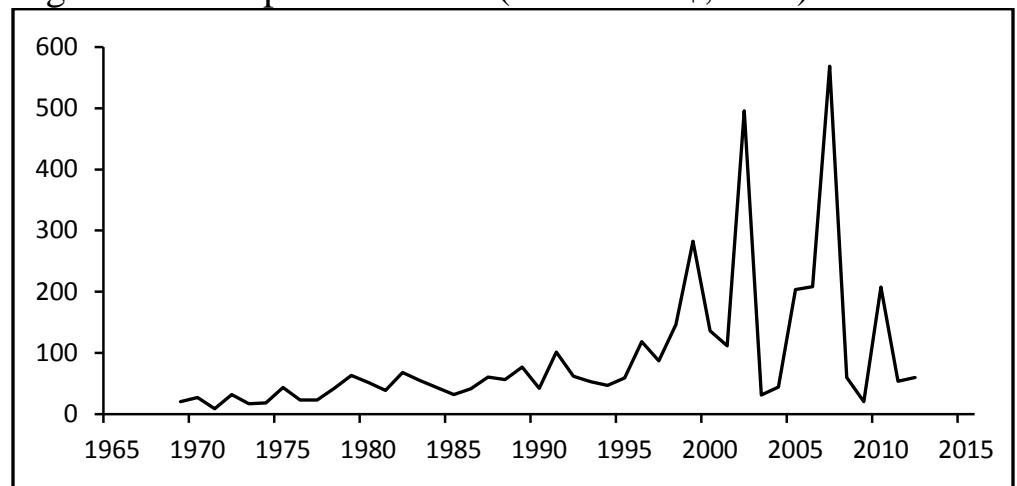

Figure 6. Jail days per individual

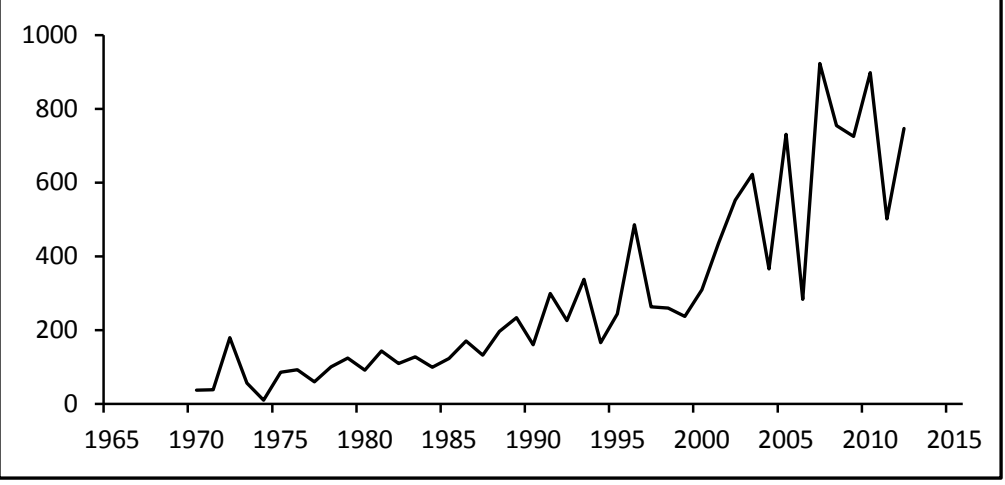


Figure 7. Estimated effects - Number of cartels prosecuted

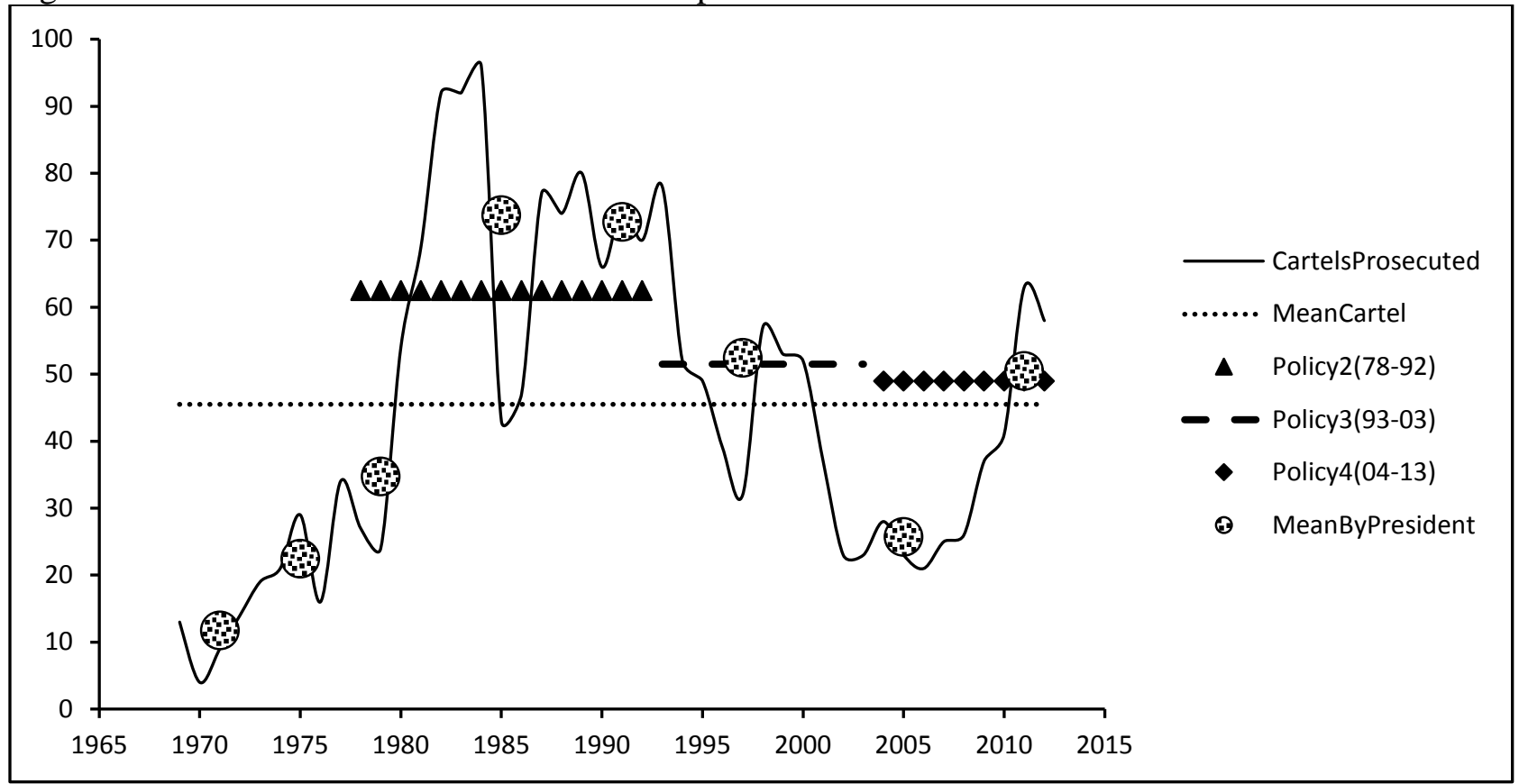

Notes:

1. MeanCartel refers to the estimated long-run mean value of the number of cartels prosecuted.

2. Policy(.) are the estimated policy period effects.

3. MeanByPresident shows the actual mean number of cartels prosecuted during each Presidential administration. The soccer balls denote the mean values during each Presidential period (the markers are roughly at the mid-point of each Presidential period): Nixon (1971); Ford (1975); Carter (1979); Reagan (1985); BushSr (1991); Clinton (1997); BushJr (2005); and Obama (2011). Note that our sample covers the years 1965-2013. We omit the Johnson period marker as the effect is subsumed in the intercept term. 
Figure 8. Estimated effects - Fines per cartel prosecuted (Real 2005 \$, ‘000)

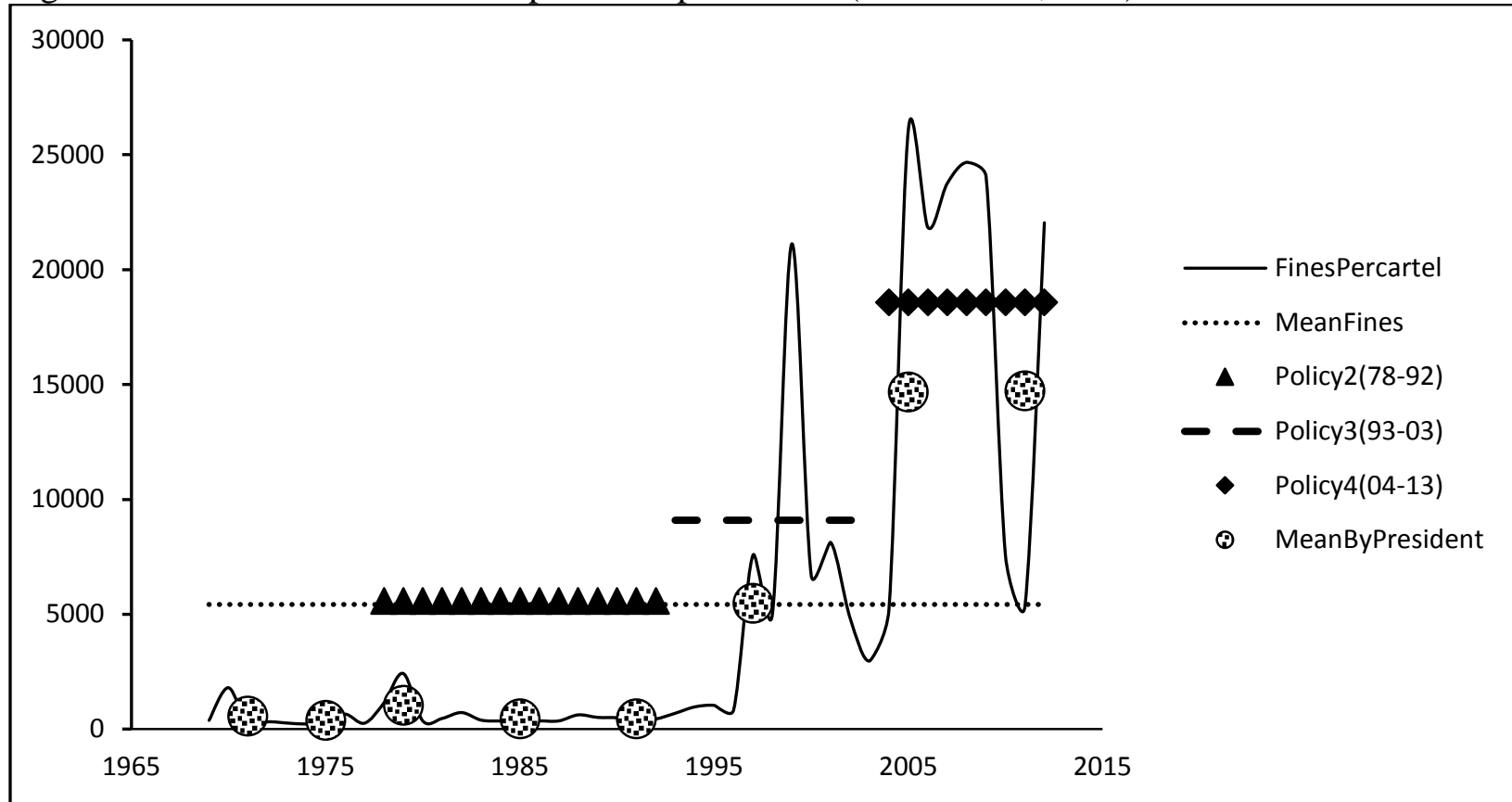

Notes:

1. MeanFines refers to the estimated long-run mean value of the fines per cartel.

2. Policy(.) are the estimated policy period effects.

3. MeanByPresident shows the actual mean number of cartels prosecuted during each Presidential administration. The soccer balls denote the mean values during each Presidential period (the markers are roughly at the mid-point of each Presidential period): Nixon (1971); Ford (1975); Carter (1979); Reagan (1985); BushSr (1991); Clinton (1997); BushJr (2005); and Obama (2011). Note that our sample covers the years 1965-2013. We omit the Johnson period marker as the effect is subsumed in the intercept term. 
Figure 9. Estimated effects - Jail days per cartel prosecuted

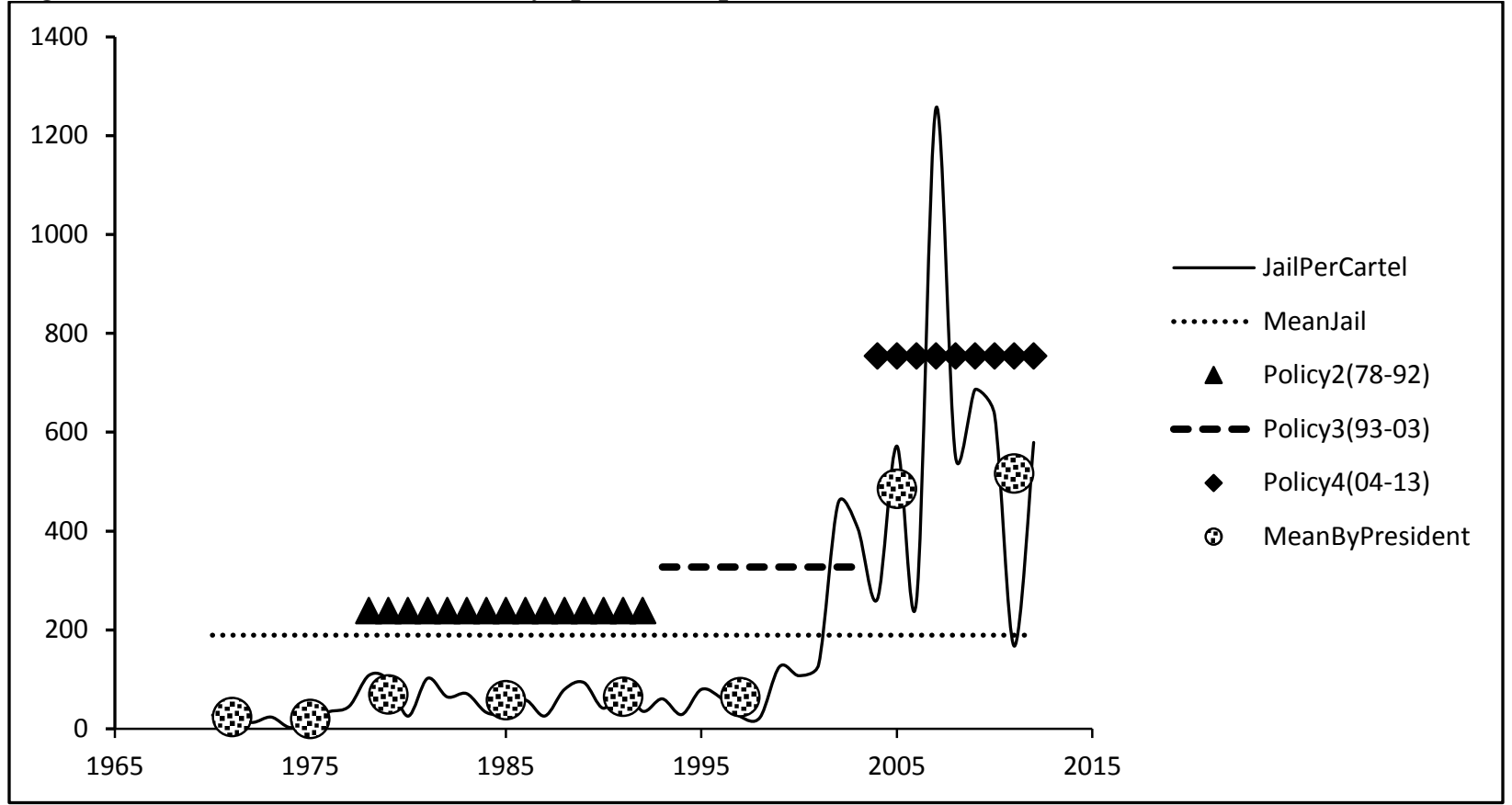

Notes:

1. MeanJail refers to the estimated long-run mean value of the jail days per cartel.

2. Policy(.) are the estimated policy period effects.

3. MeanByPresident shows the actual mean number of cartels prosecuted during each Presidential administration. The soccer balls denote the mean values during each Presidential period (the markers are roughly at the mid-point of each Presidential period): Nixon (1971); Ford (1975); Carter (1979); Reagan (1985); BushSr (1991); Clinton (1997); BushJr (2005); and Obama (2011). Note that our sample covers the years 1965-2013. We omit the Johnson period marker as the effect is subsumed in the intercept term. 
Ghosal \& Sokol. Policy, Politics, Cartel Enforcement | September 2015

Figure 10. Total EC cartel cases

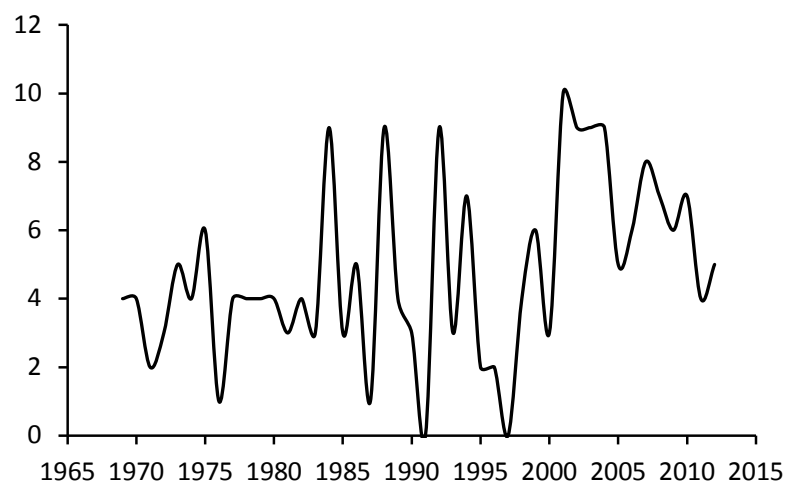

Figure 11. EC fines per cartel (Real $2005 \$$, '000)

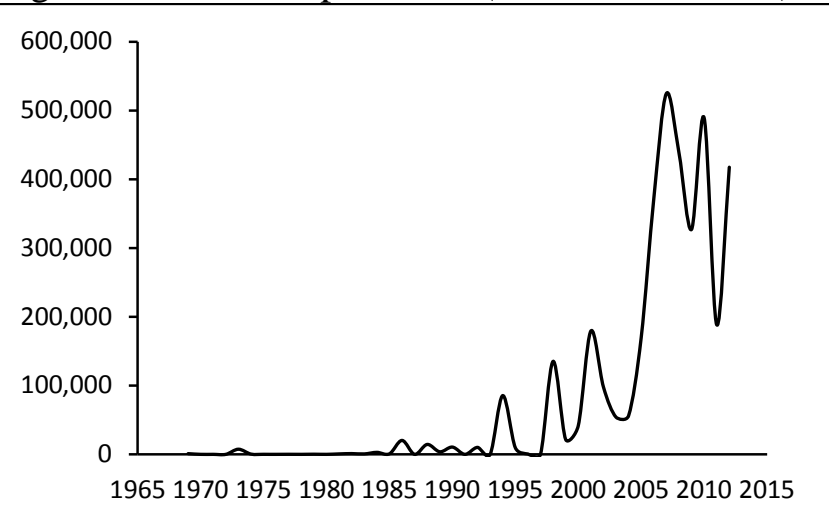


Ghosal \& Sokol. Policy, Politics, Cartel Enforcement | September 2015

Table 1. Selected U.S. antitrust developments

\begin{tabular}{|l|}
\hline 1898: Sherman Act \\
\hline 1908: U.S. v. American Tobacco \\
\hline 1930s: Thurman Arnold prioritizes international cartel enforcement \\
\hline 1945: U.S. $v$. Aluminum Company of America \\
\hline 1955: Maximum cartel fine increased \\
\hline 1959: U.S. $v$. McDonough Co. \\
\hline 1957-61: Electrical equipment cartel cases \\
\hline 1974: Antitrust Procedures and Penalties Act \\
\hline 1977-78: U.S. $v$. Continental Group, et al. \\
\hline 1977-79: U.S. uranium cartel litigation and international responses \\
\hline 1978: Original U.S. leniency program \\
\hline 1979: Hart Scott Rodino Act, first full year of implementation \\
\hline 1981: Reagan inaugurated, subsequent changes in enforcement \\
\hline 1981: U.S. $v$. B\&B Construction Co. \\
\hline 1982: FTAIA \\
\hline 1984: Criminal Fine Enforcement Act \\
\hline 1987: U.S. Sentencing Guidelines (1984) applied to all offenses \\
\hline 1990: Antitrust Amendments Act (1990) \\
\hline 1993: Revised leniency program \\
\hline 1996: Lysine cartel \\
\hline 1996: First use of the alternative fine statute (18 USC 3571(d)) \\
\hline 2004: Congress passes ACPERA \\
\hline 2006: Congress amends wiretapping statute to include antitrust violations \\
\hline 2012: DOJ closes Atlanta, Philadelphia and Cleveland field offices \\
\hline
\end{tabular}


Ghosal \& Sokol. Policy, Politics, Cartel Enforcement | September 2015

Table 2. Summary statistics

\begin{tabular}{|l|r|r|}
\hline Variable & Mean & Std. Deviation \\
\hline Total number of cartels prosecuted & 44.60 & 24.43 \\
\hline Total fines per cartel in & 5316.78 & 8189.84 \\
\hline Total jail days per cartel & 183.95 & 256.19 \\
\hline Number of individuals sentenced per cartel & 1.26 & 1.56 \\
\hline Number of firms convicted per cartel & 1.89 & 2.72 \\
\hline Fine per individual & 91.74 & 112.67 \\
\hline Fine per firm & 10142.22 & 16332.45 \\
\hline Jail days per individual & 306.85 & 255.94 \\
\hline Ratio of individuals jail to sentenced & 0.47 & 0.22 \\
\hline Total investigations & 274.11 & 118.90 \\
\hline GDP growth & 2.80 & 2.08 \\
\hline
\end{tabular}

Notes:

1. All fines are measured in \$ thousands (real 2005 \$).

2. GDP growth change measured by percent. 
Ghosal \& Sokol. Policy, Politics, Cartel Enforcement | September 2015

Table 3. Broad Prosecution Effects

\begin{tabular}{|c|c|c|c|c|c|}
\hline & & \multicolumn{2}{|c|}{ Per cartel penalties } & \multicolumn{2}{|c|}{ Total penalties } \\
\hline & $\begin{array}{r}\text { Total cartels } \\
\text { prosecuted }\end{array}$ & Fines per cartel & $\begin{array}{r}\text { Jail days per } \\
\text { cartel }\end{array}$ & Total fines & Total jail days \\
\hline $\begin{array}{l}\text { Policy2 } \\
1978-1992\end{array}$ & $\begin{array}{l}16.37 * \\
(0.070)\end{array}$ & $\begin{array}{l}278.87 \\
(0.682)\end{array}$ & $\begin{array}{l}55.02 * \\
(0.096)\end{array}$ & $\begin{array}{r}-57,776.00 \\
(0.277)\end{array}$ & $\begin{array}{r}3,253.13^{*} \\
(0.041)\end{array}$ \\
\hline $\begin{array}{l}\text { Policy3 } \\
\text { 1993-2003 }\end{array}$ & $\begin{array}{r}1.87 \\
(0.783)\end{array}$ & $\begin{array}{r}5,006.41^{*} \\
(0.023)\end{array}$ & $\begin{array}{r}186.95 * \\
(0.019)\end{array}$ & $\begin{array}{r}184,964.00^{*} \\
(0.051)\end{array}$ & $\begin{array}{r}4,511.57^{*} \\
(0.034)\end{array}$ \\
\hline $\begin{array}{l}\text { Policy4 } \\
2004-2013\end{array}$ & $\begin{array}{r}0.73 \\
(0.875) \\
\end{array}$ & $\begin{array}{r}14,073.00^{*} \\
(0.001)\end{array}$ & $\begin{array}{r}610.20 * \\
(0.005)\end{array}$ & $\begin{array}{r}463,465.00^{*} \\
(0.001)\end{array}$ & $\begin{array}{r}18,877.00^{*} \\
(0.002)\end{array}$ \\
\hline President & $\begin{array}{r}-6.90 \\
(0.142) \\
\end{array}$ & $\begin{array}{r}2,451.81 \\
(0.201) \\
\end{array}$ & $\begin{array}{r}84.54 \\
(0.270) \\
\end{array}$ & $\begin{array}{r}-127,077.00 \\
(0.185) \\
\end{array}$ & $\begin{array}{r}-2,727.04 \\
(0.210) \\
\end{array}$ \\
\hline Intercept & $\begin{array}{l}19.92 * \\
(0.012)\end{array}$ & $\begin{array}{r}-3,210.54 \\
(0.130)\end{array}$ & $\begin{array}{r}-6.04 \\
(0.932)\end{array}$ & $\begin{array}{r}127,431.00^{*} \\
(0.021)\end{array}$ & $\begin{array}{r}5,865.70^{*} \\
(0.039)\end{array}$ \\
\hline$L D V_{t-1}$ & $\begin{array}{r}0.61 * \\
(0.001)\end{array}$ & $\begin{array}{r}0.23 \\
(0.251)\end{array}$ & $\begin{array}{r}-0.15 \\
(0.494)\end{array}$ & $\begin{array}{r}-0.01 \\
(0.945)\end{array}$ & $\begin{array}{r}-0.19 \\
(0.332)\end{array}$ \\
\hline$G D P_{t-1}$ & $\begin{array}{r}-1.43 \\
(0.197)\end{array}$ & $\begin{array}{r}503.71 * \\
(0.097)\end{array}$ & $\begin{array}{l}-14.73^{*} \\
(0.064)\end{array}$ & $\begin{array}{r}4408.82 * \\
(0.065)\end{array}$ & $\begin{array}{r}-992.88^{*} \\
(0.001)\end{array}$ \\
\hline Busy $_{t-1}$ & $\begin{array}{r}-10.59 \\
(0.383)\end{array}$ & $\begin{array}{r}2,262.04 \\
(0.524)\end{array}$ & $\begin{array}{r}-54.98 \\
(0.587)\end{array}$ & $\begin{array}{r}15,710.00 \\
(0.916)\end{array}$ & $\begin{array}{r}-3,525.26 \\
(0.348)\end{array}$ \\
\hline $\bar{R}^{2}$ & 0.681 & 0.586 & 0.582 & 0.447 & 0.638 \\
\hline$\rho$ & -0.151 & -0.184 & -0.096 & -0.088 & -0.075 \\
\hline
\end{tabular}

Notes:

1. All specifications are estimated using annual time-series, 1969-2013.

2. Total fines and total jail days (last two columns) are the aggregate annual values for all cartels prosecuted.

3. Policy regime periods are as follows:

Policy1: $\leq 1977$. Pre-old leniency period.

Policy2: 1978-1992. Old leniency to new leniency period.

Policy3: 1993-2003. New leniency and Antitrust Amendments Act period.

Policy4: 2004-2013. Post-ACPERA period.

4. President is a dummy variable: Republican=1.

5. $L D V$ is the lagged-dependent variable.

6. $p$-values computed from robust standard errors (two-tailed test) are in parentheses. A p-value $<0.001$ is reported as 0.001 . An asterisk * denotes significance at least at the $10 \%$ level. $\rho$ denotes the first-order autocorrelation. 
Ghosal \& Sokol. Policy, Politics, Cartel Enforcement | September 2015

Table 4. Individual and Firm Penalties

\begin{tabular}{|c|c|c|c|c|c|c|}
\hline & $\begin{array}{r}\text { Individuals } \\
\text { sentenced per } \\
\text { cartel }\end{array}$ & $\begin{array}{r}\text { Firms } \\
\text { convicted per } \\
\text { cartel }\end{array}$ & $\begin{array}{r}\text { Fines per } \\
\text { firm }\end{array}$ & $\begin{array}{r}\text { Fines per } \\
\text { individual }\end{array}$ & $\begin{array}{r}\text { Jail days per } \\
\text { individual }\end{array}$ & $\begin{array}{r}\text { Ratio: } \\
\text { individuals } \\
\text { jailed to } \\
\text { sentenced }\end{array}$ \\
\hline $\begin{array}{l}\text { Policy2 } \\
1978-1992\end{array}$ & $\begin{array}{c}-1.33^{*} \\
(0.034)\end{array}$ & $\begin{array}{c}-2.25^{*} \\
(0.033)\end{array}$ & $\begin{array}{r}96.05 \\
(0.903)\end{array}$ & $\begin{array}{l}41.26 * \\
(0.015)\end{array}$ & $\begin{array}{c}98.08 * \\
(0.017)\end{array}$ & $\begin{array}{r}0.07 \\
(0.482)\end{array}$ \\
\hline $\begin{array}{l}\text { Policy3 } \\
1993-2003\end{array}$ & $\begin{array}{c}-1.75^{*} \\
(0.009)\end{array}$ & $\begin{array}{c}-3.59 * \\
(0.002)\end{array}$ & $\begin{array}{r}7,249.37^{*} \\
(0.049)\end{array}$ & $\begin{array}{r}187.53^{*} \\
(0.008)\end{array}$ & $\begin{array}{r}352.72 * \\
(0.001)\end{array}$ & $\begin{array}{r}0.05 \\
(0.638) \\
\end{array}$ \\
\hline $\begin{array}{l}\text { Policy4 } \\
\text { 2004-2013 }\end{array}$ & $\begin{array}{c}-1.56^{*} \\
(0.020) \\
\end{array}$ & $\begin{array}{c}-3.53^{*} \\
(0.003) \\
\end{array}$ & $\begin{array}{r}20,685.05^{*} \\
(0.003)\end{array}$ & $\begin{array}{r}175.90 * \\
(0.012) \\
\end{array}$ & $\begin{array}{r}646.37^{*} \\
(0.001) \\
\end{array}$ & $\begin{array}{r}0.37 * \\
(0.001) \\
\end{array}$ \\
\hline President & $\begin{array}{r}-0.32 \\
(0.165) \\
\end{array}$ & $\begin{array}{r}-0.66 \\
(0.158) \\
\end{array}$ & $\begin{array}{r}2,628.59 \\
(0.417) \\
\end{array}$ & $\begin{array}{l}81.58 * \\
(0.098)\end{array}$ & $\begin{array}{r}37.75 \\
(0.440) \\
\end{array}$ & $\begin{array}{r}0.05 \\
(0.165) \\
\end{array}$ \\
\hline Intercept & $\begin{array}{r}2.28^{*} \\
(0.008)\end{array}$ & $\begin{array}{r}4.25^{*} \\
(0.003)\end{array}$ & $\begin{array}{r}-4,005.49 \\
(0.229)\end{array}$ & $\begin{array}{r}-42.78 \\
(0.347)\end{array}$ & $\begin{array}{r}104.97 \\
(0.131)\end{array}$ & $\begin{array}{r}0.50 * \\
(0.004)\end{array}$ \\
\hline$L D V_{t-1}$ & $\begin{array}{r}0.05 \\
(0.621) \\
\end{array}$ & $\begin{array}{c}-0.01^{*} \\
(0.895)\end{array}$ & $\begin{array}{r}0.43^{*} \\
(0.018)\end{array}$ & $\begin{array}{r}-0.16 \\
(0.309)\end{array}$ & $\begin{array}{r}-0.11 \\
(0.548)\end{array}$ & $\begin{array}{r}-0.20 \\
(0.180) \\
\end{array}$ \\
\hline$G D P_{t-1}$ & $\begin{array}{r}0.04 \\
(0.389) \\
\end{array}$ & $\begin{array}{r}0.06 \\
(0.485) \\
\end{array}$ & $\begin{array}{r}649.84 \\
(0.204) \\
\end{array}$ & $\begin{array}{r}-0.17 \\
(0.975)\end{array}$ & $\begin{array}{l}-21.43^{*} \\
(0.023)\end{array}$ & $\begin{array}{c}-0.03^{*} \\
(0.048)\end{array}$ \\
\hline Busy $_{t-1}$ & $\begin{array}{r}-0.28 \\
(0.699)\end{array}$ & $\begin{array}{r}-0.07 \\
(0.957)\end{array}$ & $\begin{array}{r}-542.53 \\
(0.924)\end{array}$ & $\begin{array}{r}-19.02 \\
(0.646)\end{array}$ & $\begin{array}{r}-116.00 \\
(0.244)\end{array}$ & $\begin{array}{r}-0.20 \\
(0.163)\end{array}$ \\
\hline $\bar{R}^{2}$ & 0.419 & 0.464 & 0.659 & 0.158 & 0.748 & 0.391 \\
\hline$\rho$ & 0.061 & -0.124 & -0.138 & -0.055 & -0.117 & 0.093 \\
\hline
\end{tabular}

Notes:

1. See notes to table 3 . 
Ghosal \& Sokol. Policy, Politics, Cartel Enforcement | September 2015

Table 5. Political Effects - Broad Prosecution

\begin{tabular}{|c|c|c|c|c|c|c|}
\hline & \multicolumn{2}{|c|}{ Cartels prosecuted } & \multicolumn{2}{|c|}{ Fines per cartel } & \multicolumn{2}{|c|}{ Jail days per cartel } \\
\hline $\begin{array}{l}\text { Policy2 } \\
\text { 1978-1992 }\end{array}$ & $\begin{array}{l}16.37^{*} \\
(0.070)\end{array}$ & - & $\begin{array}{l}278.87 \\
(0.682)\end{array}$ & - & $\begin{array}{c}55.02^{*} \\
(0.096)\end{array}$ & - \\
\hline $\begin{array}{l}\text { Policy3 } \\
1993-2003\end{array}$ & $\begin{array}{r}1.87 \\
(0.783)\end{array}$ & - & $\begin{array}{r}5,006.41^{*} \\
(0.023)\end{array}$ & - & $\begin{array}{r}186.95 * \\
(0.019)\end{array}$ & - \\
\hline $\begin{array}{l}\text { Policy4 } \\
2004-2013\end{array}$ & $\begin{array}{r}0.73 \\
(0.875)\end{array}$ & - & $\begin{array}{r}14,073.00^{*} \\
(0.001)\end{array}$ & - & $\begin{array}{r}610.20 * \\
(0.005)\end{array}$ & - \\
\hline President & $\begin{array}{r}-6.90 \\
(0.142)\end{array}$ & - & $\begin{array}{r}2,451.81 \\
(0.201)\end{array}$ & - & $\begin{array}{r}84.54 \\
(0.270)\end{array}$ & - \\
\hline Ford & - & $\begin{array}{r}1.63 \\
(0.760)\end{array}$ & - & $\begin{array}{l}897.08 \\
(0.357)\end{array}$ & - & $\begin{array}{r}-24.01 \\
(0.424)\end{array}$ \\
\hline Carter & - & $\begin{array}{l}18.23^{*} \\
(0.038)\end{array}$ & - & $\begin{array}{l}-32.37 \\
(0.967)\end{array}$ & - & $\begin{array}{l}78.23^{*} \\
(0.009)\end{array}$ \\
\hline Reagan & - & $\begin{array}{l}40.24 * \\
(0.001)\end{array}$ & - & $\begin{array}{l}429.38 \\
(0.412)\end{array}$ & - & $\begin{array}{c}35.32^{*} \\
(0.073)\end{array}$ \\
\hline BushSr & - & $\begin{array}{l}38.22 * \\
(0.002)\end{array}$ & - & $\begin{array}{l}544.92 \\
(0.182)\end{array}$ & - & $\begin{array}{r}36.66 \\
(0.184)\end{array}$ \\
\hline Clinton & - & $\begin{array}{l}25.80^{*} \\
(0.008) \\
\end{array}$ & - & $\begin{array}{r}3,251.90 \\
(0.176) \\
\end{array}$ & - & $\begin{array}{l}60.09^{*} \\
(0.010)\end{array}$ \\
\hline BushJr & - & $\begin{array}{r}4.89 \\
(0.274)\end{array}$ & - & $\begin{array}{r}9,959.03^{*} \\
(0.018)\end{array}$ & - & $\begin{array}{r}482.90^{*} \\
(0.008)\end{array}$ \\
\hline Obama & - & $\begin{array}{l}20.18^{*} \\
(0.016)\end{array}$ & - & $\begin{array}{r}7,198.07 \\
(0.219)\end{array}$ & - & $\begin{array}{r}477.09 * \\
(0.001)\end{array}$ \\
\hline Intercept & $\begin{array}{l}19.92^{*} \\
(0.012)\end{array}$ & $\begin{array}{l}14.72^{*} \\
(0.006)\end{array}$ & $\begin{array}{r}-3,210.54 \\
(0.130)\end{array}$ & $\begin{array}{r}-1,142.12 \\
(0.216)\end{array}$ & $\begin{array}{r}-6.04 \\
(0.932)\end{array}$ & $\begin{array}{c}68.01^{*} \\
(0.012)\end{array}$ \\
\hline$L D V_{t-1}$ & $\begin{array}{r}0.61 * \\
(0.001)\end{array}$ & $\begin{array}{r}0.30 * \\
(0.079)\end{array}$ & $\begin{array}{r}0.23 \\
(0.251)\end{array}$ & $\begin{array}{r}0.39 * \\
(0.044)\end{array}$ & $\begin{array}{r}-0.15 \\
(0.494)\end{array}$ & $\begin{array}{r}-0.06 \\
(0.735)\end{array}$ \\
\hline$G D P_{t-1}$ & $\begin{array}{r}-1.43 \\
(0.197)\end{array}$ & $\begin{array}{r}-1.20 \\
(0.293)\end{array}$ & $\begin{array}{r}503.71 * \\
(0.097)\end{array}$ & $\begin{array}{r}374.40 \\
(0.222)\end{array}$ & $\begin{array}{c}-14.73^{*} \\
(0.064)\end{array}$ & $\begin{array}{c}-15.31^{*} \\
(0.031)\end{array}$ \\
\hline Busy $_{t-1}$ & $\begin{array}{r}-10.59 \\
(0.383)\end{array}$ & $\begin{array}{l}-10.35 \\
(0.285)\end{array}$ & $\begin{array}{r}2,262.04 \\
(0.524)\end{array}$ & $\begin{array}{r}1,272.58 \\
(0.753)\end{array}$ & $\begin{array}{r}-54.98 \\
(0.587)\end{array}$ & $\begin{array}{r}-38.74 \\
(0.565)\end{array}$ \\
\hline $\bar{R}^{2}$ & 0.681 & 0.736 & 0.586 & 0.461 & 0.582 & 0.530 \\
\hline$\rho$ & -0.151 & -0.176 & -0.184 & -0.108 & -0.096 & -0.097 \\
\hline
\end{tabular}

Notes:

1. See notes to table 3.

2. The estimates in columns 2, 4 and 6 replicate the estimates from table 3 . The specifications in columns 3,5 and 7 omit the Policy(.) variables and the aggregate Presidential dummy, and include a dummy for each President. The Policy(.) variables and dummies for each President cannot be included in the same specification due to collinearity. The other control variables are the same. 